\title{
IS APOLIPOPROTEIN E $\varepsilon 2$ ASSOCIATED WITH DELAYED ONSET OF NON-LESIONAL TEMPORAL LOBE EPILEPSY?
}

\author{
Davor Sporiš ${ }^{1,2}$, Silvio Bašićc ${ }^{1,2}$, Jadranka Sertić ${ }^{3}$, Darija Mahović Lakušić ${ }^{4}$ and Tomislav Babić ${ }^{5}$ \\ ${ }^{1}$ Osijek School of Medicine, Josip Juraj Strossmayer University, Osijek; ${ }^{2}$ Dubrava University Hospital, \\ Department of Neurology; ${ }^{3}$ Zagreb University Hospital Center, Clinical Institute of Laboratory Diagnosis; \\ ${ }^{4}$ Department of Neurology, Zagreb, Croatia; ${ }^{5}$ Worldwide Clinical Trials, London, UK
}

\begin{abstract}
SUMMARY - The aim of the study was to evaluate the possible association between Apo E polymorphisms and age at seizure onset in patients with non-lesional temporal lobe epilepsy. Eighty patients with non-lesional temporal lobe epilepsy with or without bilateral tonic-clonic propagation were analyzed. Age at seizure onset was defined as age at the first unequivocal seizure (excluding febrile convulsions). ApoE alleles were determined by a procedure where genome DNA was amplified by chain reaction along with polymerase, using the LightCycler kit (Roche) for ApoE mutations on codons 112 and 158 . There was a statistically significant difference between the groups of patients with ApoE $\varepsilon 2 / 3$ and $\varepsilon 3 / 4$ genotypes ( $\mathrm{p}=0.03$ ), but not between patients with $\mathrm{ApoE} \varepsilon 2 / 3$ and $\varepsilon 3 / 3$, and those with $\mathrm{ApoE} \varepsilon 3 / 4$ and $\varepsilon 3 / 3$. In conclusion, the results of our study suggested positive association of a specific ApoE genotype and onset of non-lesional temporal lobe epilepsy.
\end{abstract}

Key words: Apolipoprotein E2; Polymorphism, genetic; Epilepsy, temporal lobe; Age at onset

\section{Introduction}

Apolipoprotein E (ApoE) as the main carrier of lipids in the brain is thought to be especially important for repair mechanisms in the central nervous system $(\mathrm{CNS})^{1-3}$. After neuronal tissue damage, the synthesis of the ApoE protein is up-regulated in the reactive astrocytes ${ }^{4,5}$. However, ApoE isoforms vary in their neuroprotective properties ${ }^{6,7}$. ApoE deficiency has been shown to adversely affect outcome after transient cerebral ischemia and head trauma. Since oxidative stress contributes to these injuries, the ability of ApoE to reduce irreversible oxidative damage was studied ${ }^{8,9}$.

The ApoE gene is a confirmed genetic risk factor that influences both the risk and age at onset of $\mathrm{Alz}^{-}$ heimer's disease and Parkinson's disease ${ }^{10}$. ApoE is also

Correspondence to: Davor Sporiš, $M D P h D$, Dubrava University Hospital, Department of Neurology, Av. Gojka Šuška 6, HR-10000

Zagreb, Croatia

E-mail: davor.sporis@kbd.hr

Received November 21, 2016, accepted December 23, 2016 associated with age at onset in some other degenerative neurological diseases ${ }^{11-14}$.

With the increasing evidence for the role of ApoE in repair mechanisms in the brain ${ }^{3}$, ApoE polymorphisms and their link to temporal lobe epilepsy (TLE) has attracted ever more attention ${ }^{15,16}$. It is therefore possible that some developmental or childhood brain injury has occurred in a person with $\mathrm{ApoE} \varepsilon 4$, and there may be a failure to repair the damage, resulting in an epileptogenic lesion.

Based on pathological data derived from temporal lobe specimens of patients with TLE, ApoE may well be accepted as one of the susceptibility genes, a marker to identify people at risk of early or delayed onset of developing epilepsy. ApoE $\varepsilon 4$ genotype is associated with an earlier onset of chronic TLE ${ }^{17}$, but some other studies were not able to find a link between TLE, onset of disease and ApoE polymorphism ${ }^{18-20}$.

The aim of this study was to evaluate the association between ApoE polymorphism and age at onset in patients with non-lesional TLE. 


\section{Patients and Methods}

\section{Patients}

In this study, 80 patients with non-lesional TLE with or without bilateral tonic-clonic propagation were analyzed during a six-year period (2006-2012). The study was conducted at Zagreb University Hospital Center and Dubrava University Hospital in $\mathrm{Za}^{-}$ greb. Diagnosis of TLE was based on clinical history, seizure semiology and interictal electroencephalographic (EEG) monitoring. Age at seizure onset was the age of the subject at the first unequivocal seizure (excluding febrile convulsions) as determined retrospectively after having collected all available information. TLE was classified as non-lesional if no epileptogenic foreign-tissue lesion was detected on brain magnetic resonance imaging (MRI; epilepsy protocol, power $1.5 \mathrm{~T}$ ). Demographic and basic characteristics of study groups are shown in Table 1 . The inclusion criteria were adult subject diagnosed with non-lesional TLE with or without secondarily generalized seizures lasting for at least three years. Subjects with a history of CNS infection, head trauma, brain tumor, cerebro-

\section{Table 1. Demographic and basic characteristics of study} groups

\begin{tabular}{|l|l|}
\hline $\begin{array}{l}\text { Demographic and basic } \\
\text { characteristics }\end{array}$ & $\mathrm{n}(\%)$ \\
\hline $\mathrm{N}$ & $80(100)$ \\
Age, mean (SD) & $40.01(\mathrm{SD}$ 13.28) \\
Sex: female & $34(42.5)$ \\
$\quad$ male & $46(57.5)$ \\
Positive genetic loading & $9(11.25)$ \\
Febrile convulsions & $13(16.25)$ \\
Perinatal accident & $8(10.00)$ \\
Partial complex seizures & $31(38.75)$ \\
Secondary generalization & $49(61.25)$ \\
\hline
\end{tabular}

vascular lesion, pseudoattacks, neurodegenerative and psychiatric disease, hippocampal sclerosis, cortical dysplasia and nonprogressive tumors and perinatal hypoxic-ischemic encephalopathy were excluded.

\section{Genotyping}

Blood samples for determination of ApoE genotype were obtained from all patients. The sample was centrifuged, the cells were separated from the liquid blood phase, and both fractions were deeply frozen. Purification of DNA from blood was done with a commercial BioSprint 15 DNA Blood Kit (Qiagen, Germantown, USA). ApoE alleles were determined by a procedure where genome DNA was amplified by chain reaction along with polymerase, using the LightCycler kit (Roche, Mannheim, Germany) for ApoE mutations on codons 112 and 158.

\section{Statistics}

Microsoft SPSS statistical package for Windows, version 10.0 was used. Results were expressed as mean value and standard deviation (SD). Differences between the groups were tested by analysis of variance (ANOVA) and post-hoc Tukey test. The p-value of $<0.05$ was considered statistically significant.

The study was approved by the local ethics committee, and all patients signed the informed consent form to take part in the study.

\section{Results}

Distribution of the alleles in patients with non-lesional TLE was as follows: $\varepsilon 2 / 3$ in seven (8.75\%) pa-

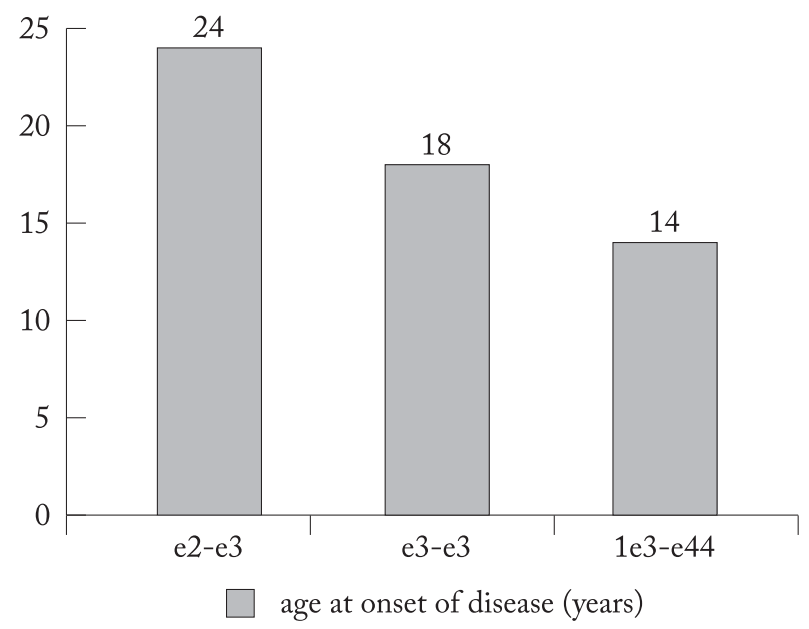

There was a statistically significant difference between the groups of patients with $\mathrm{ApoE} \varepsilon 2 / 3$ and $\varepsilon 3 / 4$ genotype ( $\mathrm{p}=0.03$ ), but not between patients with $\mathrm{ApoE} \varepsilon 2 / 3$ and $\varepsilon 3 / 3$, and those with Apo E $\varepsilon 3 / 4$ and $\varepsilon 3 / 3$. Differences between the groups were tested by analysis of variance (ANOVA) and post-hoc Tukey test. The p-value of $<0.05$ was considered statistically significant.

Fig. 1. Age at onset of temporal lobe seizure and ApoE genotype polymorphism. 
tients, $\varepsilon 3 / 3$ in $57(71.25 \%)$ patients and $\varepsilon 3 / 4$ in 16 (20.00\%) patients. There were no patients with ApoE $2 / 2,2 / 4$, and $4 / 4$ genotypes.

The average age at onset of temporal lobe seizure was $24 \pm 11$ years in patients with ApoE $\varepsilon 2 / 3$ genotype, $14 \pm 8$ in patients with ApoE $\varepsilon 3 / 4$ genotype, and $18 \pm 9$ years in those with ApoE $\varepsilon 3 / 3$ genotype. There was a statistically significant difference between the groups of patients with ApoE $\varepsilon 2 / 3$ and $\varepsilon 3 / 4$ genotypes $(\mathrm{p}=0.03)$, but not between the patients with $\mathrm{ApoE}$ $\varepsilon 2 / 3$ and $\varepsilon 3 / 3$ genotypes, and those with ApoE $\varepsilon 3 / 4$ and $\varepsilon 3 / 3$ genotypes (Fig. 1).

\section{Discussion}

Study results showed that patients with non-lesional TLE and Apo E $\varepsilon 2 / 3$ genotype had a statistically significantly delayed onset of disease as compared to patients with ApoE $\varepsilon 3 / 4$ genotype. Patients with ApoE $\varepsilon 3 / 3$ genotype also had the average age at onset of disease four years later than patients with Apo E $\varepsilon 3 / 4$ genotype and six years earlier than patients with ApoE $\varepsilon 2 / 3$, but difference between these groups of patients did not reach statistical significance. A small sample size might be one of the reasons for this. The frequency of ApoE alleles among our subjects was similar to that reported in healthy European population. The results may suggest an association of ApoE $\varepsilon 2$ and recovery/plasticity of the cell membrane, but may also support the possible neuroprotective role of ApoE $\varepsilon 2$ genotype in patients with delayed onset of disease and less protective role of ApoE $\varepsilon 4$ genotype in patients with earlier onset of disease.

Our results are consistent with those reported from the study by Briellmann et al., where apoE $\varepsilon 4$ allele was associated with an earlier onset of $\mathrm{TLE}^{17}$. Patients with e4 allele had the average age at onset of disease ten years earlier than patients without e4 allele. Moreover, as the majority of patients had an early childhood lesion, these findings suggest that ApoE e4 allele may have an important effect on determining the length of the silent interval. In contrast to this, there was no difference in the age at onset of epilepsy in patients with focal seizures with copy of the e2, e3 or e4 allele in studies by Kilpatric et al. ${ }^{18}$ and Blumke et al. ${ }^{19}$. The same result has been reported by Yeni et al..$^{20}$ in a group of patients suffering from mesial temporal lobe epilepsy-hippocampal sclerosis, and by Kauffman et al. ${ }^{21}$.
The neuroprotective properties of $\mathrm{ApoE}$ isoforms were investigated in several experimental studies on cell cultures and on mice. ApoE $\varepsilon 2$ and ApoE \&3, in contrast to ApoE $\varepsilon 4$, enhance neuronal growth and increase resistance of cell cultures to oxidative stress ${ }^{22}$. The presence of recombinant human $\mathrm{ApoE} \varepsilon 2$ in primary mixed neuronal-glial cell cultures partially protected against oxidative injury by reducing secondary glutamate excitotoxicity ${ }^{23}$. Furthermore, ApoE deficient mice are more prone to oxidative tissue damage after ischemia than mice with normal ApoE production $^{8}$. Similarly, transgenic mice with the ApoE $\varepsilon 3 / 3$ genotype have a better neurological outcome and survival rate after ischemic and oxidative stress than mice with the ApoE $\varepsilon 4 / 4$ genotype $^{9,24}$. These results clearly indicate a neuroprotective effect of Apo $\mathrm{E}$ by preserving the integrity of neuronal membranes, with ApoE $\varepsilon / A p o E \varepsilon 2$ being more effective than Apo E $\varepsilon 4$.

The neuroprotective role of ApoE polymorphism and oxidative stress caused by free radicals were also investigated in some other chronic degenerative neurological diseases. The epsilon 4 allele of the ApoE gene has been consistently associated with an earlier onset of Alzheimer's and Parkinson's disease ${ }^{10,25,26}$. The ApoE e4 allele seems to predispose carriers with multiple sclerosis to faster progression of the disease ${ }^{13}$. In Wilson's disease, the ApoE genotype was established as an important factor delaying the onset of neurological and hepatic symptoms ${ }^{14}$. The presence of Apo E e3/3 attenuates clinical manifestation by a mechanism that may involve the antioxidant and membranestabilizing properties of the ApoE $\varepsilon 3$ protein, while the onset of symptoms was significantly delayed in patients with the ApoE $\varepsilon 3 / 4$ genotype. ApoE $\varepsilon 2$ is protective against earlier onset of amyotrophic lateral sclerosis with an average age at onset in $\mathrm{ApoE} \varepsilon 2 \mathrm{car}-$ riers approximately 3 years later than in non-ApoE $\varepsilon 2$ carriers $^{11}$.

In conclusion, results of our study suggest that polymorphism of ApoE genotype might be a marker that is associated with the onset of disease in patients with non-lesional TLE.

\section{References}

1. Mathley RW. Apolipoprotein E: cholesterol transport protein with expanding role in cell biology. Science. 1988;240:622-30, doi: 10.1126/science. 3283935 . 
2. Han SH, Einstein G, Weisgraber KH, Strittmatter WJ, Saunders AM, Pericak-Vance MA, Roses AD, Schmechel DE. Apolipoprotein E is localised to the cytoplasm of human cortical neurons. J Neropathol Exp Neurol. 1994;53(5):535-44.

3. Weisgraber KH, Roses AD, Strittmatter WJ. The role of apolipoprotein E in the nervous system. Curr Opin Lipidol. 1994; 5:110-6.

4. Pitas RE, Boyles JK, Lee SH, Foss D, Mahley RW. Astrocytes synthesize apolipoprotein $\mathrm{E}$ and metabolize apolipoprotein E-containing lipoproteins. Biochim Biophys Acta. 1987;917: 148-61, http://dx.doi.org/10.1016/0005-2760(87)90295-5.

5. Nathan BP, Bellosta S, Sanan DA, Weisgraber KH, Mahley RW, Pitas RE. Differential effects of apolipoprotein E3 and E4 on neuronal growth in vitro. Science. 1994;264:850-2, doi: 10.1126/science.8171342.

6. Xu PT, Schmechel D, Rothrock T, Qui HL, Popko B, Maeda N, Saunders AM, Roses AD, Gilbert JR. Expression of human isoform specific apolipoprotein E2 and E4 in transgenic mice. Am J Hum Genet. 1995;57:A254, http://dx.doi.org/10.1006/ nbdi. 1996.0023.

7. Masliah E, Mallory M, Ge N, Alford M, Veinbergs I, Roses AD. Neurodegeneration in the central nervous system of apoE-deficient mice. Exp Neurol. 1995;136:107-22, doi: 10.1006/exnr.1995.1088.

8. Hayek T, Oiknine J, Brook JG, Aviram M. Increased plasma and lipoprotein lipid peroxidation in apo E-deficient mice. Biochem Biophys Res Commun. 1994;201:1567-74, doi: 10.1006/bbrc.1994.1883.

9. Sheng H, Laskowitz DT, Bennett E, Schmechel DE, Bart RD, Saunders AM. Apolipoprotein E isoform-specific differences in outcome from focal ischemia in transgenic mice. J Cereb Blood Flow Metab. 1998;18:361-6, doi: 10.1097/00004647199804000-00003.

10. Poirier J. Apolipoprotein E in animal models of CNS injury and in Alzheimer's disease. Trends Neurosci. 1994;17:525-30, http://dx.doi.org/10.1016/0166-2236(94)90156-2.

11. Li YJ, Pericak-Mance MA, Haines JL, Siddique N, Mc KennaYasek D, Hung XY, Sapp P, Allen CI, Chen W, Hosler B, Saunders AM, Dellefave LM, Brown RH, Siddique T. Apolipoprotein $\mathrm{E}$ is associated with age at onset of amyotrophic lateral sclerosis. Neurogenetics. 2004;5(4):209-13, doi:10.1007/ s10048-004-0193-0.

12. Zettersberg H, Jacobsson J, Rosengren L, Blennow K, Andersen PM. Association of APOE with age at onset of sporadic amyotrophic lateral sclerosis. J Neurol Sci. 2008;273(1-2):67-9, doi:10.1016/j.jns.2008.06.025.

13. Chapman J, Vinokurov S, Achiron A. APOE genotype is a major predictor of long-term progression of disability in MS. Neurology. 2001;56:312-6, doi: http://dx.doi.org/10.1212/ WNL.56.3.312.

14. Schiefermeier M, Kollegger H, Madl C, Polli C, Oder W, Kuhn HJ. The impact of apolipoprotein E genotypes on age at onset of symptoms and phenotypic expression in Wilson's disease. Brain. 2000;123:585-90, https://doi.org/10.1093/brain/ 123.3.585.
15. Kumar A, Tripathi M, Pandey RM, Ramakrishnan L, Srinivas M, Luthra K. Apolipoprotein E in temporal lobe epilepsy: a case-control study. Dis Markers. 2006;22(5-6):335-42, doi: 10.1155/2006/951632.

16. Sporis D, Sertic J, Henigsberg N, Mahovic D, Bogdanovic N, Babic T. Association of refractory complex partial seizures with a polymorphism of ApoE genotype. J Cell Mol Med. 2005; 9(3):698-703, doi:10.1111/j.1582-4934.2005.tb00500.

17. Briellmann RS, Torn Broers Y, Busuttil BE, Major BJ, Kalnins RM, Olsen M, Jackson GD, Frauman AG, Berkovic SF. ApoE epsilon 4 genotype is associated with an earlier onset of chronic temporal lobe epilepsy. Neurology. 2000;55(3):435-7, doi: 10.1212/WNL.55.3.435.

18. Kilpatric ES, Jagger CE, Spooner RJ, Brodie MJ. Apolipoprotein E and epilepsy. Ann Clin Biochem. 1996;33:146-7.

19. Blumke I, Brockhaus A, Scheiwe C, Rollbrocker B, Wolf HK, Elger CE, Wiestler OD. The apolipoprotein E epsilon allele is not associated with early onset temporal lobe epilepsy. Neuroreport. 1997;8(5):1235-7.

20. Yeni SN, Ozkara C, Buyru N, Baykara O, Hanoglu L, Karaagac N, Ozyurt E, Uzan M. Association between APOE polymorphisms and mesial temporal lobe epilepsy with hippocampal sclerosis. Eur J Nerol. 2005;12(2):103-7, doi: 10.1111/j.14681331.2004.00956.

21. Kauffman MA, Consalvo D, Moron DG, Lereis VP, Kochen S. ApoE epsilon 4 genotype and the age at onset of temporal lobe epilepsy: a case control study and meta-analysis. Epilepsy Res. 2010;90(3):234-9,doi: 10.1016/j.eplepsyres.2010.05.007.

22. Miyata M, Smith JD. Apolipoprotein E allele-specific antioxidant activity and effects on cytotoxicity by oxidative insults and beta-amyloid peptides. Nature Genet. 1996;14:55-61, doi: 10.1038/ng0996-55.

23. Lee Y, Mitsuo A, Laskowitz D, Warner DS, Pearlstein RD. Apolipoprotein $\mathrm{E}$ protects against oxidative stress in mixed neuronal-glial cell cultures by reducing glutamate toxicity. Neurochem Int.2004;44(2):107-18, http://dx.doi.org/10.1016/ S0197-0186(03)00112-8.

24. Buttini M, Akeefe H, Lin C, Mahley RW, Pitas RE, WyssCoray T, Mucke L. Dominant negative effects of apolipoprotein $\mathrm{E} 4$ revealed in transgenic models of neurodegenerative disease. Neuroscience. 2000;97(2):207-10, http://dx.doi.org/ 10.1016/S0306-4522(00)00069-5.

25. Conejero-Goldberg C, Gomar JJ, Bobes-Bascaran T, Hyde TM, Kleinman JE, Herman MM, Chen S, Davies P, Goldberg TE. ApoE2 enhances neuroprotection against Alzheimer's disease through multiple molecular mechanisms. Mol Psychiatry. 2014;19(11):1243-50, doi: 10.1038/mp.2013.194.

26. Keeney JT, Ibrahimi S, Zhao L. Human ApoE isoforms differentially modulate glucose and amyloid metabolic pathways in female brain: evidence of the mechanism of neuroprotection by ApoE2 and implications for Alzheimer's disease prevention and early intervention. J Alzheimers Dis. 2015;48(2):411-24, doi: 10.3233/JAD-150348. 


\section{Sažetak \\ POVEZANOST APOLIPOPROTEINA E $\varepsilon 2$ S KASNIJIM POČETKOM EPILEPSIJE TEMPORALNOG REŽNJA}

D. Sporiš, S. Bašić, J. Sertić, D. Mahović Lakušić i T. Babić

Cilj ovoga istraživanja bio je utvrditi moguću povezanost genskog polimorfizma ApoE s dobno ranijim početkom bolesti kod bolesnika s epilepsijom temporalnog režnja i negativnim nalazom magnetske rezonancije mozga. U istraživanje je bilo uključeno 80 bolesnika s epilepsijom temporalnog režnja i negativnim nalazom magnetske rezonancije mozga. Dob početka bolesti definirana je kao dob pojavnosti prvog neprovociranog epilepsijskog napadaja (isključujući febrilne konvulzije). ApoE aleli su određeni postupkom pri kojem je genomska DNA amplificirana lančanom reakcijom uz polimerazu, a korišten je detekcijski kit LightCycler (Roche) za mutacije ApoE na kodomu 112 i 158. Utvrđena je značajna statistička razlika između skupina bolesnika s genotipom ApoE $\varepsilon 2 / 3$ i $\varepsilon 3 / 4$ (p=0,03), dok između bolesnika s ApoE ع2/3 i $\varepsilon 3 / 3$ i onih s ApoE $\varepsilon 3 / 4$ i ع3/3 nije bilo značajne statističke razlike. Rezultati istraživanja ukazuju na moguću povezanost specifičnog genotipa ApoE $\mathrm{i}$ dobi početka bolesti kod bolesnika s epilepsijom temporalnog režnja i negativnim nalazom magnetske rezonancije mozga.

Ključne riječi: Apolipoprotein E2; Polimorfizam, genetski; Epilepsija temporalnog režnja; Dob pojave bolesti 